\title{
The Impact of Dividend Policy on the Relationship Between Institutional Ownership and Stock Price Volatility: Evidence from Pakistan
}

\section{Atif Hussain*}

\begin{abstract}
This study aims to determine the effects of dividend policy on the relationship between institutional ownership and stock price volatility, based on a sample of 36 firms listed on the Karachi Stock Exchange over a seven-year period (2005-11). We use a fixed-effects model applied to panel data to investigate this relationship and find that institutional ownership has a negative relation with stock price volatility and a positive relation with the dividend payout ratio. The results also show that dividend payouts significantly affect the relationship between institutional ownership and stock price volatility. The mediating role of dividend policy between institutional ownership and stock price volatility reveals that institutional investors prefer to invest in low-volatility dividend-paying stock.
\end{abstract}

Keywords: Dividend policy, institutional ownership, stock price volatility, Pakistan.

JEL classification: G30, G35.

\section{Introduction}

As active investors, institutions spend a huge amount on equity trading in the hopes that active investment will prove profitable (French, 2008). The most important question in corporate finance is whether a change in institutional ownership will affect stock returns. Institutional owners, having better information, will reduce the stock volatility, but a number of studies show a positive relation between the two.

Chen and Hong (2006) show that institutional owners are more well-informed investors than other equity traders. If institutional investors incorporate the information they have into stock trading, they are likely to be in a position to affect stock prices (El-Gazzar, 1998; Loderer, Cooney, \& van Drunen, 2012). Similarly, if they buy a particular security, they will

* The author is a doctoral candidate at Preston University in Kohat, and can be contacted at atif_n2a@yahoo.com. 
likely create an upward movement in the supply curve and thus affect the stock return (Sias, Starks, \& Titman, 2006).

Dividend policy plays a prominent role in determining the direction of the relationship between institutional ownership and stock price volatility. Institutional ownership is negatively related to stocks on which no dividend is paid and positively to stocks on which a dividend is paid (Rubin \& Smith, 2009). Institutional investors make investments on behalf of other investors; under the institutional preference hypothesis, they prefer to invest in nondividend-paying stock, which is characterized by low price volatility. However, Grinstein and Michaely (2005) find that institutional investors do invest in dividend-paying stock. The institutional turnover hypothesis also shows that institutional owners rotate their stock portfolios more regularly than others, which increases stock volatility (Karpoff, Malatesta, \& Walkling, 1996).

The central objective of a dividend policy is to maximize shareholders' wealth (Arnold, 2008). According to the agency theory, agency cost is reduced by the payment of dividends, which encourages managers to pay more dividends rather than investing in less profitable projects. The literature also finds that institutional owners maintain close relations with managers to keep themselves apprised of firms' prospects, which results in less stock variance (Jensen \& Meckling, 1976); Easterbrook, 1984; Ryan \& Schneider, 2002).

Pakistan is an emerging country with high-risk and high-return stock markets where investors look for greater market premiums (Nishat, 1999). Insider trading by brokers makes stock prices more volatile (Khwaja \& Mian, 2005) while government reforms in the 1990s opened up local markets to foreign investors, leading to increased stock volatility. The reforms pertaining to dividend policy included the following: shifting from cash dividends to stock dividends, tax exceptions for right/bonus shares, and tax seals on cash dividends. Studies on Pakistan have focused on the relationship between dividend policy and stock price volatility (see, for example, Nazir, Nawaz, Anwar, \& Ahmed, 2010; Nishat \& Bilgrami, 1994; Nishat \& Irfan, 2001; Rashid \& Rehman, 2008). However, no study investigates the impact of institutional ownership on stock price volatility.

This study focuses on the relation between institutional investors and stock price volatility by looking at the mediating impact of dividend policy. Its main objectives are: 
- To determine the impact of institutional ownership on dividend policy in Pakistan

- To assess the impact of institutional ownership on stock price volatility in Pakistan

- To investigate the impact of dividend policy on the relationship between institutional ownership and stock price volatility in Pakistan

To our knowledge, this is the first study on Pakistan that provides empirical evidence for the impact of institutional ownership on stock price volatility. Its findings could, therefore, prove useful to researchers, individual investors, and institutional investors.

\section{Literature Review}

Almost all existing studies on this topic have established the significant and positive link between institutional investors and variations in stock prices (see, for example, Dennis \& Strickland, 2002; Sias, 1996; Xu \& Malkiel, 2004). Institutional portfolio earnings are normally greater than individual portfolio earnings, and stock return volatility therefore increases with an increase in the level of institutional owners (Karpoff, 1987; Rubin, 2007). However, Rubin and Smith (2009) argue that the association between institutional investors and variations in stock prices depends significantly on firms' dividend payments. They establish a constructive association for dividend-paying stocks and an unconstructive one for stocks on which no dividend is paid.

West (1988) notes that having more price information decreases stock price instability. Since institutional owners are more knowledgeable than individual owners (see Bartov, Radhakrishnan, \& Krinsky, 2000; Alangar, Bathala, \& Rao, 1999; Szewczyk \& Tsetsekos, 1992), they are likely to make fewer errors in evaluating their information (Sias, 1996). Nondividend firms are subject to less variation in stock prices, given the strong relation between information and institutional owners (Khang \& King, 2006; Li, Ortiz-Molina, \& Zhao, 2008).

Managers and optimistic traders may decide to concentrate first and foremost on information that yields returns in the short term rather than the long term (De Long \& Shleifer, 1991; Froot \& Obstfeld, 1992). Dividend announcements are trustworthy, voluntarily observable, and short-term, i.e., announced quarterly. Investors need not wait long for these announcements to translate into stock prices (Lakonishok, Shleifer, \& Vishny, 1992), in turn, directing institutions to pursue and trade on them. 
In addition, managers who are concerned about their professional reputation (see Scharfstein \& Stein, 1990; Shiller, Fischer, \& Friedman, 1984) are likely to follow information that may be unfairly interpreted. Moreover, dividend-paying firms are likely to have fewer information irregularities than nondividend payers (Khang \& King, 2006; Li et al., 2008). These concerns make institutions trade in a similar way on receiving news concerning dividend-paying firms.

Although many researchers have explored the relationship between dividend policy and the instability of share prices (see Allen \& Rachim, 1996; Hussainey, Oscar Mgbame, \& Chijoke-Mgbame, 2011; Nazir et al., 2010; Asghar, Shah, Hamid, \& Suleman, 2011), their conclusions are not necessarily consistent. Baskin (1989) establishes a considerably negative relationship between dividend yield and stock price instability (see also Hussainey et al., 2011).

In view of their fiduciary obligations, institutional investors may be restricted from selecting unstable stocks (Sias, 1996; Bohl \& Brzeszczynski, 2006). Their accountability as fund managers, their constant requirement for liquidity, and the stress of meeting their clients' interests may discourage them from investing in riskier stocks. Arbel, Carvell, and Strebel (1983) note that an increase in institutional trading decreases stock instability rather than increasing it. Yang (2002) finds that foreign institutional investor trading stabilizes market prices in Taiwan, while Bohl and Brzeszczynski (2006) establish a similar relationship for Poland.

Numerous studies show that institutional investors' individual dealings have a direct effect on prices. For instance, Keim and Madhavan (1997) assess the trades for 21 organizations over 26 months and find that institutional investors generally purchase stocks at a 0.31 percent premium and sell them at a 0.34 percent discount relative to the preceding day's close. Chan and Lakonishok (1995) assess the trades of 37 investment managers over 18 months and show that their individual trades have both temporary as well as longer effects. If, as the model of trades in these studies suggests, the trades of individual institutional investors have a certain price effect, collective institutional trading will also have a subsequent price effect, that is, it will mirror the increasing effect of the individual institutional investors' trades.

On the other hand, under economies of scale, institutional investors are expected to be more well-informed than other traders. If trading by institutional investors discloses information, then institutional trading will 
influence prices (Easley \& O'Hara, 1987; Kyle, 1995). A number of empirical tests propose that the information exposed during trading is mainly accountable for stock price changes (see Scholes, 1972; French \& Roll, 1986; Barclay, Litzenberger, \& Warner, 1990). If the information that arises in the course of trading is the most important cause of stock price changes, and institutional investors are more likely to be informed than individual investors, collective institutional trading will, subsequently, have return effects.

The literature reviewed above indicates the knowledge gap on stock price volatility in Pakistan, especially with regard to empirical evidence on the relationship between institutional ownership and stock price volatility. This study is the first of its type to look at the impact of institutional ownership on stock price volatility based on the mediating effect of dividend policy.

\section{Framework and Methodology}

This section describes the conceptual framework used, the variables employed, and the methodology applied.

\subsection{Conceptual Framework}

Based on the literature survey above, we develop the following conceptual model (Figure 1).

Figure 1: Schematic model for conceptual framework

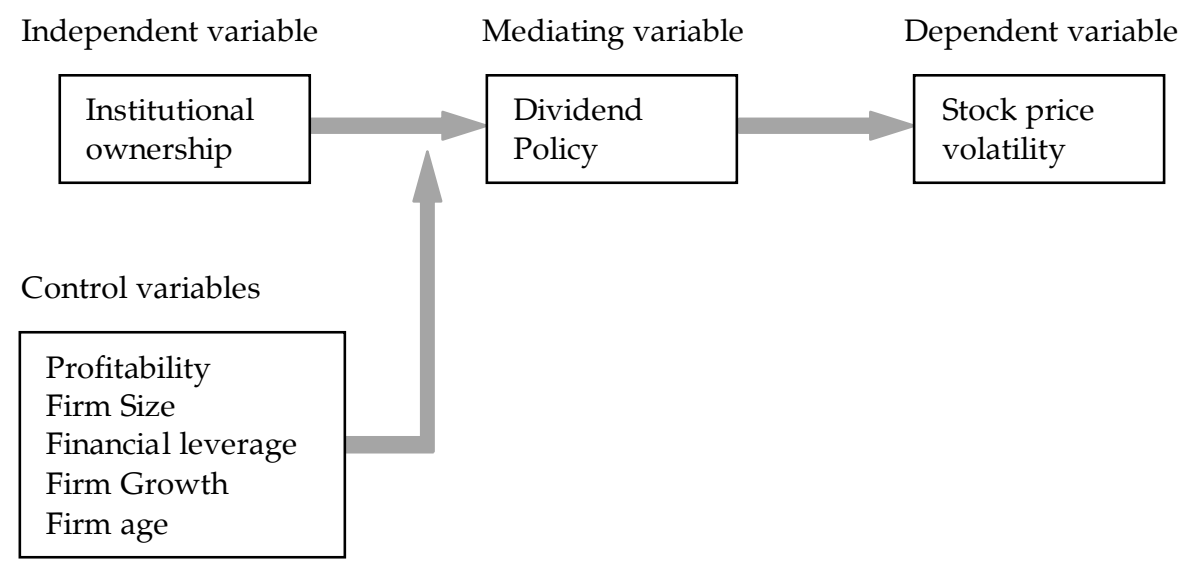




\subsection{Variables}

We take stock price volatility as the dependent variable; risk is used as a proxy for stock price volatility and is measured as the standard deviation of the daily return on a stock for a given year (see Azzam, 2010; Bennett, Sias, \& Starks, 2003; Ferreira \& Matos, 2008; Gompers, Ishii, \& Metrick, 2003). Dividend policy is the mediating variable, where the dividend payout ratio (dividend per share/earnings per share) is used as a proxy for dividend policy (see Azzam, 2010; Nazir et al., 2010). Institutional ownership is the independent variable, where we consider institutional owners to be those with a share of 5 percent or more (see Azzam, 2010; Demsetz \& Villalonga, 2001).

Many other factors affect stock price volatility, including profitability (Azzam, 2010; Rubin \& Smith, 2009), firm size (Azzam, 2010; Nazir et al., 2010), firm age (Pastor \& Veronesi, 2003), financial leverage (Azzam, 2010; Nazir et al., 2010; Pastor \& Veronesi, 2003), and firm growth (Azzam, 2010; Pastor \& Veronesi, 2003; Rubin \& Smith, 2009). These are taken as control variables in this study. Table 1 summarizes the variables above and their expected interrelationship.

Table 1: Summary of variables

\begin{tabular}{|c|c|c|c|}
\hline Variable & Abbreviation & Definition/calculation & \\
\hline \multicolumn{4}{|l|}{ Dependent variables } \\
\hline Stock price volatility & Vlt & $\begin{array}{l}\text { Standard deviation of the daily } \\
\text { return on a stock for a given year }\end{array}$ & \\
\hline \multicolumn{4}{|l|}{ Mediating variable } \\
\hline Dividend payout ratio & DPO & $\begin{array}{l}\text { Dividend per share/earnings per } \\
\text { share }\end{array}$ & - \\
\hline \multicolumn{4}{|l|}{ Independent variable } \\
\hline Institutional ownership & Inst & $5 \%$ of shares or more & - \\
\hline \multicolumn{4}{|l|}{ Control variables } \\
\hline Return on assets & ROA & Net profit/total assets & - \\
\hline Firm size & Size & Log of total assets & - \\
\hline Financial leverage & FL & Total liabilities/shareholders' equity & + \\
\hline Growth & $\mathrm{M} / \mathrm{B}$ & $\begin{array}{l}\text { Market price per share/book value } \\
\text { per share }\end{array}$ & + \\
\hline Firm age & Age & Age of firm in 2011 & - \\
\hline
\end{tabular}




\subsection{Study Hypotheses}

We base this study on the following hypotheses:

- H1: Institutional ownership has a significant impact on stock price volatility.

- H2: Institutional ownership has a significant impact on dividend policy.

- H3: Dividend policy has a significant impact on stock price volatility.

- H3: Dividend policy has a significant impact on the relationship between institutional ownership and stock price volatility.

\subsection{Methodology}

This study is a time-series cross-sectional study (see Baltagi, 2009; Wooldridge, 2001) that aims to determine the impact of institutional ownership on stock price volatility, given the mediating effect of dividend policy. Our sample is drawn from firms listed on the Karachi Stock Exchange with the assumption that listed firms present their profits to stakeholders to make their shares more attractive (Lazaridis \& Tryfonidis, 2006). The sample has been drawn on the basis of the following criteria:

- The sample firms must have 5 percent or more institutional owners.

- The firms must be profitable firms in the period covered by the study.

- The firms must have paid dividends in the period covered by the study.

The study covers a period of 10 years from 2003 to 2012. The final sample comprises 400 firm-year observations for 40 firms.

We have used SPSS (20.0) for analysis purposes and described the data with the help of Durrheim (2002). Correlation analysis is used to determine the degree of association among the different variables (see Bailey, 2007). A fixed-effects model is used to determine the intercept differences of the sample companies. The model assumes that the explanatory variables are related to each firm's own effect. The variable $\eta_{i}$ is taken as the dummy variable to determine the particular effect of each firm, and $\lambda_{t}$ is used as a dummy variable for time, which remains constant across firms but varies over time (see Park, 2005).

The following models are used for regression analysis: 


$$
\begin{aligned}
& V l t=\beta_{0}+\beta_{1} \text { Inst }_{i}+\beta_{2} \text { Size }_{i}+\beta_{3} \text { Levrg }_{i}+\beta_{4} \text { ROA }_{i}+\beta_{5} \text { Age }_{i}+\beta_{6} M / B_{i}+\eta_{i}+\lambda_{i}+\varepsilon_{i t} \\
& D P O=\beta_{0}+\beta_{1} \text { Inst }_{i}+\beta_{2} \text { Size }_{i}+\beta_{3} \text { Levrg }_{i}+\beta_{4} R O A_{i}+\beta_{5} \text { Age }_{i}+\beta_{6} M / B_{i}+\eta_{i}+\lambda_{i}+\varepsilon_{i t} \\
& V l t=\beta_{0}+\beta_{1} D P O_{i}+\beta_{2} \text { Size }_{i}+\beta_{3} \text { Levrg }_{i}+\beta_{4} R O A_{i}+\beta_{5} \text { Age }_{i}+\beta_{6} M / B_{i}+\eta_{i}+\lambda_{i}+\varepsilon_{i t} \\
& V l t=\beta_{0}+\beta_{1} D P O_{i}+\beta_{2} \text { Inst }_{i}+\beta_{3} \text { Size }_{i}+\beta_{4} \text { Levrg }_{i}+\beta_{5} R O A_{i}+\beta_{6} A g e_{i}+\beta_{7} M / B_{i}+\eta_{i}+\lambda_{i}+\varepsilon_{i t}
\end{aligned}
$$

\section{Results and Discussion}

\subsection{Descriptive Statistics}

Table 2 gives the mean values, range, and standard deviations of the different variables. Stock price volatility for the sample firms has a mean of 0.648 with a standard deviation of 0.346 . The dividend payouts variable has a mean value of 37.1 percent and a standard deviation of 21.3 percent. The institutional owners variable has a mean percentage share of 38.1 percent.

Table 2: Descriptive statistics

\begin{tabular}{lccc}
\hline Variable & Range & Mean & Std. deviation \\
\hline Vit & 1.166 & 0.648 & 0.246 \\
DPO & 3.543 & 0.371 & 0.476 \\
Inst & 0.743 & 0.381 & 0.213 \\
ROA & 0.730 & 0.214 & 0.229 \\
Size & 1.940 & 0.337 & 0.399 \\
FL & 1.120 & 0.523 & 0.229 \\
M/B & 43.460 & 2.771 & 3.678 \\
Age & 32.000 & 13.602 & 12.432 \\
\hline
\end{tabular}

Source: Author's calculations.

As a proxy for profitability, return on assets has a mean of 21.4 percent with a standard deviation of 22.9 percent. The size of the firm is measured by the log of total assets, i.e., the value of firm size is 0.337 . Financial leverage, measured by total liability/total assets, has a mean value of 52.3 percent with a standard deviation of 23.1 percent. The market-to-book value is used as a proxy for growth and has a mean value of 2.771 . The mean age of the firm up to 2011 is 13.602 years with a standard deviation of 2.432 . 


\subsection{Correlation Results}

The correlation results for the different variables are given in Table 3. The correlation between the dividend payout ratio and stock price volatility is $-0.053(p<=0.01)$, showing that dividend payments decrease with stock price volatility in Pakistan. The results also show that institutional ownership has a correlation coefficient of $-0.160(p<=0.05)$ with stock price volatility. This negative relationship implies that firms with greater institutional ownership have low stock price volatility.

The correlation between stock price volatility and return on assets is also negative and significant, showing that firm profits decrease with stock price volatility. The correlation between financial leverage and stock price volatility is 0.129 ( $p<=0.05)$, implying that firms with high liabilities face greater stock price volatility. Firm age has a negative correlation coefficient of $-0.012(p<=0.05)$ with dividend policy. Firm size and market-to-book value have no significant relationship with stock price volatility.

The correlation between institutional ownership and the dividend payout ratio is $0.143(p<=0.05)$, implying that firms with a greater share of institutional ownership pay higher dividends. Return on assets has a coefficient of $0.211(p<=0.05)$ with the dividend payout ratio, showing that firms with greater profitability pay higher dividends. The correlation between financial leverage and the dividend payout ratio is -0.191 ( $p<=$ 0.01), indicating that firms with a high debt burden pay low or no dividends. Firm age has a positive correlation with the dividend payout ratio, implying that mature firms pay more dividends than newly established ones. Firm size and the market-to-book value have no significant relationship with the dividend payout ratio.

Table 3: Correlation results

\begin{tabular}{lllllllll}
\hline Var. & \multicolumn{1}{c}{ Vlt } & \multicolumn{1}{c}{ DPO } & Inst & ROA & Size & FL & M/B & Age \\
\hline Vlt & 1.000 & & & & & & & \\
DPO & $-0.053^{* *}$ & 1.000 & & & & & & \\
Inst & $-0.160^{*}$ & $0.143^{*}$ & 1.000 & & & & & \\
ROA & $-0.311^{*}$ & $0.211^{*}$ & $0.115^{* *}$ & 1.000 & & & & \\
Size & 0.011 & 0.130 & -0.112 & $-0.075^{*}$ & 1.000 & & & \\
FL & $0.129^{*}$ & $-0.191^{* *}$ & $-0.022^{* *}$ & $-0.222^{* *}$ & $0.051^{* *}$ & 1.000 & & \\
M/B & 0.132 & 0.194 & $0.024^{* *}$ & $0.0655^{*}$ & $0.011^{* *}$ & $-0.014^{*}$ & 1.000 & \\
Age & $-0.012^{*}$ & -0.016 & 0.011 & 0.024 & 0.132 & -0.122 & $0.145^{* *}$ & 1.000 \\
\hline
\end{tabular}

Note: ${ }^{* *}=$ significant at $1 \%,{ }^{*}=$ significant at $5 \%$.

Source: Author's calculations. 


\subsection{Regression Results}

\subsubsection{Relationship Between Institutional Ownership and Stock Price Volatility}

Model 1 in Table 4 shows the impact of institutional ownership on stock price volatility. Institutional ownership has a beta estimate of -0.433 with $t=-4.211$ and a p-value of 0.002 . This shows that institutional ownership has a negative impact on stock price volatility. Pastor and Veronesi (2003), Lin et al. (2008), and Rubin and Smith (2009), among others, also find a negative relationship between stock institutional ownership and stock price.

The reason for this negative relationship is that many firms in Pakistan are small and depend heavily on institutional investors for financing. Since institutional investors commonly have more information on the business environment, they carry out more informed trading, leading to more informative, and thus more stable, stock prices (West, 1988). The prudent-man rule also prevents institutional owners from investing in risky or more volatile stock (Oak \& Dalbor, 2008).

Return on assets (coefficient $=-0.012 ; t=-2.161$, $\mathrm{p}$-value $=0.041$ ) has a significantly negative impact on stock volatility. Rubin and Smith (2009) and Azzam (2010) also find a negative relation between profitability and stock price volatility, implying that highly profitable firms face lower stock price volatility due to low uncertainty in their business operations. Financial leverage (coefficient $=0.216, t=5.072$, p-value $=0.000$ ) has a significantly positive relationship with stock price volatility. Pastor and Veronesi (2003) and Azzam (2010) also report a positive relationship between financial leverage and stock price volatility. Greater firm liabilities decrease the profit margin and thus create uncertainty about the firm, which results in stock price volatility. 
Table 4: Model 1 estimates: Dependent variable $=$ Vlt

\begin{tabular}{lccc}
\hline Variable & Estimates & $\mathbf{t}$ & Sig. \\
\hline Inst & $-0.433^{* * *}$ & -4.211 & 0.002 \\
DPO & & & \\
ROA & $-0.012^{* *}$ & -2.161 & 0.041 \\
FL & $0.216^{* * *}$ & 5.072 & 0.000 \\
Size & $-0.009^{* * *}$ & -3.570 & 0.006 \\
M/B & -0.334 & 0.145 & 0.488 \\
Age & $-0.231^{* *}$ & -3.046 & 0.019 \\
R sq. & 0.311 & & \\
F-stat & 6.863 & & \\
F sig. & 0.000 & & \\
\hline
\end{tabular}

Note: ${ }^{* *}=$ significant at $1 \%,{ }^{* *}=$ significant at $5 \%,{ }^{*}=$ significant at $10 \%$.

Source: Author's calculations.

Firm size has a negative relationship with stock volatility (coefficient $=-0.009, t=-3.570, \mathrm{p}$-value $=0.006$ ). This result is consistent with Sias (1996) and Azzam (2010), showing that large firms in Pakistan face less price volatility. The market-to-book value has a positive and significant impact on stock price volatility (coefficient $=0.334 ; t=2.145$, $\mathrm{p}$ value $=0.028$. This positive relation indicates that growing firms face high stock price volatility due to high risk (Pastor \& Veronesi, 2003; Rubin \& Smith, 2009). Firm age (coefficient $=-0.231, t=-3.046$, p-value $=0.019$ ) has a negative and significant impact on stock volatility. Pastor and Veronesi (2003) also find a negative relation between the age of the firm and stock price volatility. Younger firms face greater uncertainty and are thus subject to more volatile stock prices as against mature firms, which face less stock price volatility due to lower uncertainty in their business operations.

\subsubsection{Relationship Between Institutional Ownership and Dividend Policy}

Model 2 in Table 5 shows the impact of institutional ownership on the dividend payout ratio. Institutional ownership has a beta estimate of 0.573 with $t=3.254$ and a p-value of 0.003 . This shows that institutional ownership has a positive and significant effect on dividend policy. A number of studies report finding a positive relationship between institutional ownership and dividend policy (see Dhaliwal, Erickson, \& Trezevant, 1999; Allen, Bernardo, \& Welch, 2000; Short, Zhang, \& Keasey, 2002; Mirza \& Afza, 2010; Afza \& Mirza, 2011). Institutional owners use dividend payments as a means of monitoring managers by forcing them to 
distribute the free cash flow in the form of dividends if there is no profitable investment opportunity, thus reducing any agency cost. Furthermore, since many Pakistani firms are small, they do not have access to the capital market and have to attract institutional investors by paying high dividends (Mirza \& Afza, 2010).

Table 5: Model 2 estimates: Dependent variable = DPO

\begin{tabular}{lccc}
\hline Variable & Estimates & $\mathbf{t}$ & Sig. \\
\hline Inst & $0.573^{* * *}$ & 3.254 & 0.003 \\
DPO & & & \\
ROA & $0.025^{* *}$ & 2.566 & 0.016 \\
FL & $-0.332^{* * *}$ & 4.623 & 0.000 \\
Size & 0.015 & 0.252 & 0.443 \\
M/B & $-0.211^{* *}$ & -2.061 & 0.029 \\
Age & $0.119^{* *}$ & 2.402 & 0.021 \\
R sq. & 0.255 & & \\
F-stat & 5.172 & & \\
F sig. & 0.000 & & \\
\hline
\end{tabular}

Note: ${ }^{* *}=$ significant at $1 \%,{ }^{* *}=$ significant at $5 \%,{ }^{*}=$ significant at $10 \%$.

Source: Author's calculations.

Return on assets (coefficient $=0.025, t=2.566$, $\mathrm{p}$-value $=0.016$ ) has a significant and positive impact on dividend policy, showing that highprofit firms in Pakistan pay higher dividends (Ahmad \& Javid, 2009; Afza $\&$ Mirza, 2011). Financial leverage (coefficient $=-0.332, t=4.623$, $\mathrm{p}$-value $=$ 0.000 ) has a significant and negative relationship with dividend policy. Aivazian, Booth, and Cleary (2003) and Afza and Mirza (2011) also report a negative relationship between financial leverage and the dividend payout ratio. This negative relationship shows that firms with a high debt percentage pay low or no cash dividends in Pakistan.

Firm size has an insignificant relationship with the dividend payout ratio (coefficient $=0.015, t=0.252$, $\mathrm{p}$-value $=0.443$ ). This result is in line with Afza and Mirza (2011) who also find a negative relationship between firm size and dividend payouts. This implies that firms' size has no effect on their dividend behavior in Pakistan. The market-to-book value has a negative and significant impact on dividend policy (coefficient $=-0.211, t=$ 2.061, $\mathrm{p}$-value $=0.029$ ), showing that growing firms pay no dividends because they use their cash reserves for further investment (see Ahmad \& Javid, 2009). Firm age (coefficient $=0.119, t=2.402$, p-value $=0.021$ ) has a 
positive and significant impact on dividend policy, implying that mature firms have excess cash reserves and thus can pay higher dividends to keep their market price stable.

\subsubsection{Relationship Between Dividend Policy and Stock Price Volatility}

Model 3 in Table 6 shows the impact of the dividend payout ratio on stock price volatility. The dividend payout ratio has a beta estimate of 0.093 with $t=-3.262$ and a p-value of 0.007 , implying that it has a negative impact on stock price volatility. This negative relationship shows that Pakistani firms that pay dividends present a positive picture of their firm's performance, thus reducing the uncertainty of their stock prices. Baskin (1989), Allen and Rachim (1996), Nazir et al. (2010), and Hussainey et al. (2011) also find a negative relationship between dividend payouts and stock price volatility, contrary to Asghar et al. (2011), who find a positive relation between dividend payouts and stock price volatility in Pakistan.

Table 6: Model 3 estimates: Dependent variable: Vlt

\begin{tabular}{lccc}
\hline Variable & Estimates & $\mathbf{t}$ & Sig. \\
\hline Inst & & & \\
DPO & $-0.093^{* * *}$ & -3.262 & 0.007 \\
ROA & $-0.033^{* *}$ & -2.561 & 0.023 \\
FL & $0.254^{* *}$ & 2.314 & 0.029 \\
Size & $-0.010^{* *}$ & -3.002 & 0.011 \\
M/B & -0.114 & -0.262 & 0.413 \\
Age & $-0.201^{* * *}$ & -3.971 & 0.000 \\
R sq. & 0.269 & & \\
F-stat & 6.143 & & \\
F sig. & 0.000 & & \\
\hline
\end{tabular}

Note: ${ }^{* *}=$ significant at $1 \%,{ }^{* *}=$ significant at $5 \%,{ }^{*}=$ significant at $10 \%$.

Source: Author's calculations.

Return on assets (coefficient $=-0.033, t=-2.561$, p-value $=0.023$ ) has a significantly negative impact on stock volatility, consistent with Rubin and Smith (2009) and Azzam (2010). Financial leverage (coefficient $=0.254, t$ $=2.314$, -value $=0.029$ ) has a significantly positive relationship with stock price volatility, in line with Pastor and Veronesi (2003) and Azzam (2010).

Firm size has a negative relationship with stock volatility (coefficient $=-0.010, t=-3.002, \mathrm{p}$-value $=0.011)$, consistent with Sias (1996) 
and Azzam (2010). The market-to-book value has an insignificant impact on stock price volatility (coefficient $=0.114, t=2.262$, $\mathrm{p}$-value $=0.023$ ). This positive result is in line with Pastor and Veronesi (2003) and Rubin and Smith (2009). Firm age (coefficient $=-0.201, t=-3.971$, p-value $=0.000$ ) has a negative and significant impact on stock volatility, consistent with Pastor and Veronesi (2003).

\subsubsection{Effect of Dividend Policy on Relationship Between Institutional Ownership and Stock Price Volatility}

Model 4 in Table 7 shows the mediating role of dividend policy in the relationship between institutional ownership and stock price volatility. The dividend payout ratio has a beta estimate of -0.085 with $t=-2.970$ and a $\mathrm{p}$-value of 0.009 . This shows that dividend payouts have a negative impact on stock price volatility. Institutional ownership also has a negative and significant effect on stock price volatility, but the beta estimate of 0.433 with $t=-4.211$ and a p-value of 0.002 in model 1 decreases to a beta estimate of -0.234 with $t=-2.017$ and a p-value of 0.043 . This shows that dividend policy partially mediates the relationship between institutional ownership and stock price volatility.

Table 7: Model 4 estimates: Dependent variable $=$ Vlt

\begin{tabular}{lccc}
\hline Variable & Estimates & $\mathbf{t}$ & Sig. \\
\hline Inst & $-0.234^{* *}$ & -2.017 & 0.043 \\
DPO & $-0.085^{* * *}$ & -2.970 & 0.009 \\
ROA & $-0.017^{* *}$ & 1.963 & 0.050 \\
FL & $0.154^{* *}$ & 2.001 & 0.044 \\
Size & $-0.003^{* *}$ & -2.555 & 0.018 \\
M/B & 0.006 & -0.153 & 0.132 \\
Age & $-0.114^{*}$ & -1.179 & 0.087 \\
R sq. & 0.117 & & \\
F-stat & 4.255 & & \\
F sig. & 0.000 & & \\
\hline
\end{tabular}

Note: ${ }^{* * *}=$ significant at $1 \%,{ }^{* *}=$ significant at $5 \%,{ }^{*}=$ significant at $10 \%$.

Source: Author's calculations.

Return on assets (coefficient $=-0.017, t=-1.963$, $\mathrm{p}$-value $=0.050$ ) has a significantly negative impact on stock volatility. Financial leverage (coefficient $=0.154, t=2.001, \mathrm{p}$-value $=0.044$ ) has a significantly positive relationship with stock price volatility. Firm size has a negative 
relationship with stock volatility (coefficient $=-0.003, t=-2.555, \mathrm{p}$-value $=$ 0.018). The market-to-book value has an insignificant relationship with stock price volatility (coefficient $=0.006, t=-0.153, p$-value $=0.132$ ). Firm age (coefficient $=-0.114, t=-1.179, \mathrm{p}$-value $=0.087$ ) has a negative impact on stock volatility. The significance level of all these control variables has decreased from that found in model 1.

Rubin and Smith (2009) and Azzam (2010) also report that dividend policy significantly affects the relationship between institutional ownership and stock price volatility. Rubin and Smith find a positive relationship between the two; Azzam, however, reports a negative relationship between institutional ownership and stock price volatility for dividend-paying stock. Our results also show a negative relationship between institutional ownership and stock price volatility for dividend-paying stock in Pakistan.

These findings are contrary to the institutional preference theory, which holds that institutional owners prefer to invest nondividend-paying firms with low price volatility. We find that institutional owners prefer to invest in dividend-paying stocks with stabilized prices. West (1988) and Pastor and Veronesi (2003) also show that nondividend firms face more stock price volatility. Our results indicate that institutional owners compel firms to make dividend payments; this signals better performance, which, in turn, stabilizes firms' stock prices.

\section{Conclusion}

This study has attempted to determine the effect of dividend policy on the relationship between institutional ownership and stock price volatility, using a sample of 104 nonfinancial firms listed on the Karachi Stock Exchange over a period of seven years (2005-2011). The effect of dividend policy on the relationship between institutional ownership and stock price volatility was investigated through panel data regression using a fixed-effects model. Stock price volatility was taken as the dependent variable, institutional ownership as the independent variable, dividend payouts as the mediating variable, and return on assets, firm size, financial leverage, firm growth, and firm age as control variables.

Our first hypothesis concerned the relationship between institutional ownership and stock price volatility. The results showed that institutional ownership has a negative and significant impact on stock price volatility, implying that institutional owners avoid investing in volatile 
stock. Furthermore, institutional owners in Pakistan are market makers and more informed traders, and thus help stabilize stock prices.

The second hypothesis deals with the relationship between institutional ownership and dividend policy. The results revealed that institutional owners have a positive and significant relationship with dividend policy: since many Pakistani firms are small, they attract big investors by paying dividends.

The third hypothesis pertains to the relationship between dividend policy and stock price volatility. The results showed that dividend policy has a negative and significant impact on stock price volatility, showing that dividend payments reduce the uncertainty in stock prices. Finally, the fourth hypothesis deals with the effect of dividend policy on the relationship between institutional ownership and stock price volatility. Our results provide significant support for this hypothesis: the mediating role of dividend policy between institutional ownership and stock price volatility reveals that institutional investors prefer to invest in lowvolatility dividend-paying stock.

Practically, these results suggest that firms can use dividend policy as a tool for reducing stock price volatility. Furthermore, regulators of the stock market must take into consideration the important role of institutional ownership in the market environment and stability. This study is limited to nonfinancial firms in Pakistan, but could be expanded to financial firms as an avenue for further research. 


\section{References}

Afza, T., \& Mirza, H. H. (2011). Institutional shareholdings and corporate dividend policy in Pakistan. African Journal of Business Management, 5(22), 8941-8951.

Ahmad, H., \& Javid, A. Y. (2009). The determinants of dividend policy in Pakistan. International Research Journal of Finance and Economics, 29, 110-125.

Aivazian, V., Booth, L., \& Cleary, S. (2003). Do emerging market firms follow different dividend policies from US firms? Journal of Financial Research, 26(3), 371-387.

Alangar, S., Bathala, C., \& Rao, R. (1999). The effect of institutional interests on the information content of dividend-change announcements. Journal of Financial Research, 22, 429-448.

Allen, D. E., \& Rachim, V. S. (1996). Dividend policy and stock price volatility: Australian evidence. Journal of Applied Economics, 6, 175188.

Allen, F., Bernardo, A., \& Welch, I. (2000). A theory of dividends-based tax clienteles. Journal of Finance, 55(6), 2499-2536.

Arbel, A., Carvell, S., \& Strebel, P. (1983). Giraffes, institutions and neglected firms. Financial Analysts Journal, 39, 55-63.

Arnold, G. (2008). Corporate financial management. London, UK: Financial Times Pitman Publishing.

Asghar, M., Shah, Z. A., Hamid, K., \& Suleman, M. T. (2011). Impact of dividend policy on stock price risk: Empirical evidence from equity market of Pakistan. Far East Journal of Psychology and Business, 4(1), 45-52.

Azzam, I. (2010). The impact of institutional ownership and dividend policy on stock returns and volatility: Evidence from Egypt. International Journal of Business, 15(4), 443-458.

Bailey, K. (2007). Methods of social research (4th ed.). New York, NY: Simon \& Schuster. 
Baltagi, B. H. (2009). A companion to econometric analysis of panel data. Chichester, UK: Wiley.

Barclay, M., Litzenberger, R., \& Warner, J. (1990). Private information, trading volume and stock return variances. Review of Financial Studies, 3, 233-253.

Bartov, E., Radhakrishnan, S., \& Krinsky, I. (2000). Investor sophistication and patterns in stock returns after earnings announcements. The Accounting Review, 75(1), 43-63.

Baskin, J. (1989). Dividend policy and the volatility of common stock. Journal of Portfolio Management, 15(3), 19-25.

Bennett, J. A., Sias, R. W., \& Starks, L. T. (2003). Greener pastures and the impact of dynamic institutional preferences. Review of Financial Studies, 16(4), 1203-1238.

Bohl, M. T., \& Brzeszczynski, J. (2006). Do institutional investors destabilize stock prices? Evidence from an emerging market. Journal of International Financial Markets, Institutions and Money, 16(4), 370-383.

Chan, L., \& Lakonishok, J. (1995). The behavior of stock prices around institutional trades. Journal of Finance, 50(4), 1147-1174.

Chen, A. S., \& Hong, B. S. (2006). Institutional ownership changes and returns around analysts' earnings forecast release events: Evidence from Taiwan. Journal of Banking and Finance, 30(9), 24712488 .

De Long, J. B., \& Shleifer, A. (1991). The stock market bubble of 1929: Evidence from closed-end mutual funds. Journal of Economic History, 51(3), 675-700.

Demsetz, H., \& Villalonga, B. (2001). Ownership structure and corporate performance. Journal of Corporate Finance, 7(3), 209-233.

Dennis, P. J., \& Strickland, D. (2002). Who blinks in volatile markets, individuals or institutions? Journal of Finance, 57(5), 1923-1949. 
Dhaliwal, D. S., Erickson, M., \& Trezevant, R. (1999). A test of the theory of tax clienteles for dividend policies. National Tax Journal, 52(2), 179-194.

Durrheim, K. (2002). Quantitative analysis. In M. Terre Blanche \& K. Durrheim (Eds.), Research in practice (pp. 96-122). Cape Town, South Africa: University of Cape Town Press.

Easley, D., \& O'Hara, M. (1987). Price, trade size, and information in securities markets. Journal of Financial Economics, 19, 69-90.

Easterbrook, F. H. (1984). Two agency-cost explanations of dividends. American Economic Review, 74(4), 650-659.

El-Gazzar, S. M. (1998). Predisclosure information and institutional ownership: A cross-sectional examination of market revaluations during earnings announcement periods. The Accounting Review, 73(1), 119-129.

Ferreira, M. A., \& Matos, P. (2008). The colors of investors' money: The role of institutional investors around the world. Journal of Financial Economics, 88(3), 499-533.

French, K. R. (2008). Presidential address: The cost of active investing. Journal of Finance, 63(4), 1537-1573.

French, K. R., \& Roll, R. (1986). Stock-return variances: The arrival of information and the reaction of traders. Journal of Financial Economics, 17, 5-26.

Froot, K. A., \& Obstfeld, M. (1992). Intrinsic bubbles: The case of stock prices (Working Paper No. 3091). Cambridge, MA: National Bureau of Economic Research.

Gompers, P., Ishii, J., \& Metrick, A. (2003). Corporate governance and equity prices. Quarterly Journal of Economics, 118(1), 107-156.

Grinstein, Y., \& Michaely, R. (2005). Institutional holdings and payout policy. Journal of Finance, 60(3), 1389-1426.

Hussainey, K., Oscar Mgbame, C., \& Chijoke-Mgbame, A. M. (2011). Dividend policy and share price volatility: UK evidence. Journal of Risk Finance, 12(1), 57-68. 
Jensen, M. C., \& Meckling, W. H. (1976). Theory of the firm: Managerial behavior, agency costs and ownership structure. Journal of Financial Economics, 3(4), 305-360.

Karpoff, J. M. (1987). The relation between price changes and trading volume: A survey. Journal of Financial and Quantitative Analysis, 22(1), 109-126.

Karpoff, J. M., Malatesta, P. H., \& Walkling, R. A. (1996). Corporate governance and shareholder initiatives: Empirical evidence. Journal of Financial Economics, 42(3), 365-395.

Keim, D., \& Madhavan, A. (1997). Transactions costs and investment style: An inter-exchange analysis of institutional equity trades. Journal of Financial Economics, 46, 265-292.

Khang, K., \& King, T.-H. D. (2006). Does dividend policy relate to crosssectional variation in information asymmetry? Evidence from returns to insider trades. Financial Management, 35(4), 71-94.

Khwaja, A. I., \& Mian, A. (2005). Unchecked intermediaries: Price manipulation in an emerging stock market. Journal of Financial Economics, 78(1), 203-241.

Kyle, A. S. (1995). Continuous auctions and insider trading. Econometrica, $53,1315-1335$.

Lakonishok, J., Shleifer, A., \& Vishny, R. W. (1992). The impact of institutional trading on stock prices. Journal of Financial Economics, 32(1), 23-43.

Lazaridis, I., \& Tryfonidis, D. (2006). Relationship between working capital management and profitability of listed companies in the Athens Stock Exchange. Journal of Financial Management and Analysis, 19(1), 32-59.

Li, K., Ortiz-Molina, H., \& Zhao, X. (2008). Do voting rights affect institutional investment decisions? Evidence from dual-class firms. Financial Management, 37(4), 713-745.

Loderer, C., Cooney, J. W., \& van Drunen, L. D. (2012). The price elasticity of demand for common stock. Journal of Finance, 46(2), 621-651. 
Mirza, H. H., \& Afza, T. (2010). Ownership structure and cash flows as determinants of corporate dividend policy in Pakistan. International Business Research, 3(3), 210-221.

Nazir, M. S., Nawaz, M. M., Anwar, W., \& Ahmed, F. (2010). Determinants of stock price volatility in Karachi Stock Exchange: The mediating role of corporate dividend policy. International Research Journal of Finance and Economics, 55, 100-107.

Nishat, M. (1999). The impact of institutional development on stock prices in Pakistan. Doctoral dissertation, Auckland Business School, University of Auckland, New Zealand.

Nishat, M., \& Bilgrami, N. (1994). Who pays dividend? An exploratory analysis of firms listed with Karachi stock market. Saving and Development, 3(18), 335-344.

Nishat, M., \& Irfan, C. M. (2001, January). Dividend policy and stock price volatility in Pakistan. Paper presented at the $16^{\text {th }}$ Annual General Meeting of the Pakistan Society of Development Economists, Islamabad.

Oak, S., \& Dalbor, M. C. (2008). The impact of dividend policy on institutional holdings: Hotel REIT and non-REIT hotel corporations. Journal of Hospitality Financial Management, 16(1), 1-17.

Park, H. M. (2005). Linear regression models for panel data using SAS, Stata, LIMDEP, and SPSS (Working paper). Bloomington, IN: Indiana University, Center for Statistical and Mathematical Computing.

Pastor, L., \& Veronesi, P. (2003). Stock prices and IPO waves (Discussion Paper No. 4002). Washington, DC: Center for Economic and Policy Research.

Rashid, A., \& Rehman, A. (2008). Dividend policy and stock price volatility: Evidence from Bangladesh. Journal of Applied Business and Economics, 8(4), 71-80.

Rubin, A. (2007). Ownership level, ownership concentration and liquidity. Journal of Financial Markets, 10(3), 219-248.

Rubin, A., \& Smith, D. R. (2009). Institutional ownership, volatility and dividends. Journal of Banking and Finance, 33(4), 627-639. 
Ryan, L. V., \& Schneider, M. (2002). The antecedents of institutional investor activism. Academy of Management Review, 27(4), 554-573.

Scharfstein, D. S., \& Stein, J. C. (1990). Herd behavior and investment. American Economic Review, 80(3), 465-479.

Scholes, M. S. (1972). The market for securities: Substitution versus price pressure and the effects of information on share prices. Journal of Business, 45, 179-211.

Shiller, R. J., Fischer, S., \& Friedman, B. M. (1984). Stock prices and social dynamics (Brookings Papers on Economic Activity No. 2). Washington, DC: Brookings Institution.

Short, H., Zhang, H., \& Keasey, K. (2002). The link between dividend policy and institutional ownership. Journal of Corporate Finance, $8(2), 105-122$.

Sias, R. W. (1996). Volatility and the institutional investor. Financial Analysts Journal, 52(2), 13-20.

Sias, R. W., Starks, L. T., \& Titman, S. (2006). Changes in institutional ownership and stock returns: Assessment and methodology. Journal of Business, 79(6), 2869-2910.

Szewczyk, S. H., \& Tsetsekos, G. P. (1992). State intervention in the market for corporate control: The case of Pennsylvania Senate Bill 1310. Journal of Financial Economics, 31(1), 3-23.

West, K. D. (1988). Dividend innovations and stock price volatility (Working Paper No. 1833). Cambridge, MA: National Bureau of Economic Research.

Wooldridge, J. M. (2001). Econometric analysis of cross-section and panel data. Cambridge, MA: MIT Press.

Xu, Y., \& Malkiel, B. (2004). Idiosyncratic risk and security returns. Paper presented at the American Finance Association 2001 New Orleans Meetings.

Yang, J. J. W. (2002). The information spillover between stock returns and institutional investors' trading behavior in Taiwan. International Review of Financial Analysis, 11(4), 533-547. 